\title{
The application and revision of a new relationship to calculate effective porosity from specific capacity on a well database in the Pacific Northwest
}

\author{
James M. Wilkinson \\ Keio University, School of Science for Open and Environmental Systems, Japan
}

\begin{abstract}
:
Previous unpublished research led to the establishment of a relationship between effective porosity and specific capacity, based on well construction data in a series of laboratory experiments. In this paper the relationship was tested on a regional aquifer system using data from 609 wells which met certain criteria. The relationship was applied to each well, with results showing that the relationship needed revision. The relationship was thus reevaluated and revised to produce results that reflected the conditions in the aquifer system which consisted of 9 layers of aquifers and aquitards of various lithologic descriptions, ranging from unconsolidated sediments to volcanic rocks. Average values of effective porosity could be calculated and the distribution of effective porosity was determined for each unit and compared with the original estimates. The result was a new relationship to determine effective porosity directly from specific capacity, which can be applied without detailed information on well construction or lithology. The new relationship is useful for distributing effective porosity within 2 or 3 dimensional groundwater and particle tracking models on a cell-by-cell basis. More importantly, the new relationship can be used to determine effective porosity for contaminant transport models.
\end{abstract}

KEYWORDS groundwater model; contaminant transport model; effective porosity; specific capacity; hydraulic properties; parameter estimations

\section{INTRODUCTION}

Several years ago, the author was part of a regional groundwater modeling team at the USGS that thought that a relationship should exist between effective porosity and other known hydraulic parameters. Several researchers have established various relationships between hydraulic properties of groundwater, but have yet to establish a quick and inexpensive method to determine effective porosity from actual measured data found on drillers' records, such as specific capacity.

A variety of methods have been developed and used for estimating effective porosity. The use of tracers is common when there are at least 1 or more wells available to sample (Domenico and Schwartz, 1991; Gloaguen et al., 2001; Haggerty et al., 1998; Hall et al., 1991; Javandel, 1989; Stephens et al., 1998; White, 1988; Yeh et al., 2000). This method is time consuming and expensive (Stephens et al., 1998), as well as highly dependent upon the groundwater gradient and hydraulic conductivity (Javandel, 1989).
Additionally Hall et al. (1991) concluded that laboratory tracer experiments did not accurately coincide with estimated results. Furthermore most tracer tests are generally used for determining hydraulic conductivity or transmissivity for use in calculating effective porosity with one of the various existing equations. Remedial workers tend to favor this method over others, and it is widely used in remedial applications.

Another common method for estimating or calculating effective porosity is through extensive laboratory testing of sediment properties such as particle size, shape, packing, sorting, pore space, etc. (Barr, 2001; Bernabé et al., 2004; Dias et al., 2004; Dunning, 2005; Jarvis et al., 2002; Kamann et al., 2007; Morin, 2006; Morris and Johnson, 1967; Sperry and Peirce, 1995; Zhang et al., 2011). A similar type of analysis uses binary mixtures in laboratory experiments. However it has been pointed out that the weak point of this method is the inability to duplicate ideal packing of large and small sediments, not to mention the infinite combinations. Research by Zhang et al. (2011) based on glass beads to simulate sediments reassured us that results from laboratory testing either overestimate or underestimate effective porosity.

This leads us to published tables of effective porosity for rocks and sediments that can be found in many textbooks and references (Domenico and Schwartz, 1991; Driscoll, 1986; Fetter, 2000; Morris and Johnson, 1967). Ranges of effective porosity have been established by compiling the results of extensive analyses of hundreds of field samples, allowing one to establish ranges of effective porosity for virtually all types of sediments and rocks. Although these ranges are useful for illustrational purposes, choosing a value from a range can introduce considerable error in models and simulations. Calibrating a model requires several iterations of trial and error to arrive at a value of effective porosity. However, this method does not take into account the spatial variability of effective porosity that exists due to the inhomogeneous nature of the lithology inherent to the depositional environment.

Several other methods have been utilized to determine the effective porosity, total porosity, and other hydraulic parameters. Cunningham (2004) describes the use of groundpenetrating radar, digital optical borehole images, and core analyses to determine effective porosity and hydraulic conductivity. These methods tend to be expensive, time consuming, and require specialist equipment. Wang et al. (2003) used laser polarized xenon nuclear magnetic resonance (NMR) methods to simultaneously determine permeability and effective porosity of oil reservoir rocks with reasonable accuracy. This method can be very useful 
but it does require equipment that makes it impractical for quick surveys. Other sources of interference when determining effective porosity are tidal and atmospheric pressure (Rojstaczer and Agnew, 1989), and biological clogging from a form of bacteria referred to as slime (Vandevivere and Baveye, 1992).

A relationship between hydraulic conductivity and effective porosity was established by combining work from Ahuja et al. (1989) and Morris and Johnson (1967) and applying an algorithm to adjust the values (Hinkle and Snyder, 1997; Morgan and McFarland, 1996). However, this method was limited to a maximum effective porosity of 35 percent.

The objective of this study is to show that a reliable relationship between specific capacity and effective porosity exists, making calculation of effective porosity relatively academic. The initial relationship is based on an equation relating hydraulic conductivity to effective porosity (Ahuja et al., 1989). This was modified with an equation that relates specific capacity and transmissivity (Razack and Huntley, 1991) which was tested in laboratory experiments (Wilkinson, Unpublished research). In this study the relationship is revised and calibrated through application of the relationship to a well database (McCarthy and Anderson, 1990) and calibrated to existing lithologic data (Swanson et al., 1993) in that well database. This is the same well database that was used by Morgan and McFarland (1996) for their research and later by Hinkle and Snyder (1997).

\section{A SUMMARY DESCRIPTION OF THE DATA}

Figure 1 shows the location of the wells in the study area, in the Portland area along the Oregon Washington border in the United States. The well database of 1586

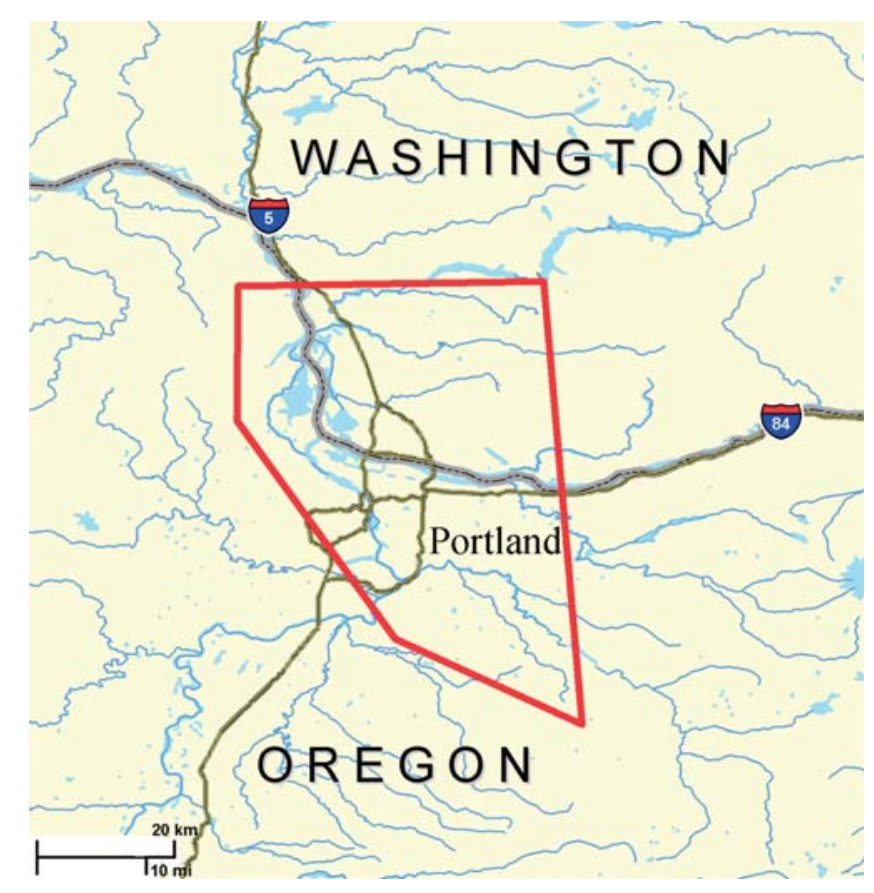

Figure 1. Location of the study area along the OregonWashington border, USA located and confirmed wells contains the construction details of the wells, including location (latitude and longitude), altitude (feet), well depth (feet), open interval (feet), well diameter (inches), and well performance data that includes test method, yield (Gpm), drawdown (feet), test period (hours), and other miscellaneous information (McCarthy and Anderson, 1990). All units were converted to metric for use in this paper.

The location is a basin with nine hydrogeologic layers, some of which have been grouped together and some that have been divided into subunits (Snyder et al., 1998). The initial hydrogeology was defined and discussed in detail in Swanson et al. (1993) which includes an appendix showing the altitude of each unit as intersected by the wells. The following is a brief summary description of each unit based on these sources.

Unit US (Unconsolidated Sediments aquifer) is a combination of flood deposits and glacial outwash. It lacks cementation and commonly has been disturbed by subsequent reworking from the local river and streams. This is a generally very productive source for groundwater; however, since it is the uppermost unit, it is highly susceptible to contaminants.

Unit TG (Troutdale Gravel aquifer) is a sandy conglomerate with lenses of lava and soil horizons. This unit lacks cementation and is generally a very productive source of groundwater.

Unit UF (Undifferentiated Fine-Grained Sediments) is fine-grained and similar to the confining units. This unit is present where $\mathrm{C} 1$ and $\mathrm{C} 2$ are not separated by TS. It consists of clay, silt, and fine sand lenses. It is not considered to be a good source of groundwater except at the local level.

Unit C1 (Confining Unit 1) is composed of clay and silt, with local lenses of fine sand. It is not used for public water supplies, although some personal water supplies draw groundwater from this unit.

Unit TS (Troutdale Sandstone aquifer) is coarse-grained sandstone with lenses of finer-grained sands. This unit is poorly to well cemented and has primary and secondary effective porosity as a result of partial dissolution of the cementation.

Unit C2 (Confining Unit 2) is composed of clay and silt, with local lenses of fine sand. Similar to $\mathrm{C} 1$, it is not used for public water supplies, although some personal water supplies draw groundwater from this unit.

Unit SG (Sand and Gravel aquifer) is composed of sandy gravel with some finer-grained lenses. However, the SG unit is subdivided into an upper coarse grained unit designated as SC, and a lower fine grained unit designated as SF. In this paper this unit is referred to as SG since the original data from Swanson et al. (1993) didn't differentiate between the upper and lower units. This unit is generally a very productive source of old groundwater, meaning that it hasn't been subjected to anthropogenic influences.

Unit OR (Older Rocks) consists mostly of volcanic and marine sedimentary rocks. The volcanic rocks were deposited from several different episodes of volcanism, each with a different mineral profile. The marine sediments are very fine grained clay and silt. Generally this unit is not used as a source of groundwater except in outlying rural areas where it is used as a household source of water.

$\mathrm{UF}, \mathrm{C} 1, \mathrm{C} 2, \mathrm{SF}$, and $\mathrm{OR}$ are considered to be aquitards 
and generally poor sources for water supplies, while US, TG, TS, and SC are generally good aquifers and good sources of water. This hydrogeologic environment represents a wide variety of conditions for effective porosity, which can vary extensively from one hydrogeologic unit to the next as well as spatially within the each hydrogeologic unit.

\section{METHODS AND CALCULATIONS}

The selection of wells was based on completeness of the data in the published database from both sources (McCarthy and Anderson, 1990; Swanson et al., 1993). The criteria for valid data were location, altitude, depth, open interval, yield, and drawdown. The resultant selection of wells was cross-referenced to the hydrogeology in Swanson et al. (1993) to assign the hydrogeologic unit to the open interval of the wells. Not all of the initially selected wells matched with hydrogeology data and the final result was 609 wells that met all of the criteria.

The initial equation that was established to describe the relationship was based on the research of Ahuja et al. (1989), who established a relationship between hydraulic conductivity and effective porosity in shallow soils, and Razack and Huntley (1991), who established a relationship between transmissivity and specific capacity. These two relationships were combined and solved for specific capacity and effective porosity. The resulting fit to the data was a logarithmic equation which was then used to modify the initial equation. This equation is:

$$
\phi_{e}=\frac{\ln \left(\sqrt{\frac{\left(\frac{Q}{S}\right)^{0.67}}{11.992 b}+1.8}\right)}{5}
$$

where $\phi_{e}$ is the dimensionless initial effective porosity, $Q$ is the yield in $\mathrm{m}^{3} /$ day, $s$ is the drawdown in meters, $b$ is the saturated thickness in meters, and specific capacity is $Q / s$ in $\mathrm{m}^{2} /$ day. An explanation of the laboratory methods used to develop equation 1 can be found in Wilkinson and Shikazono (2012).

\section{REVISION AND CALIBRATION OF THE RELATIONSHIP}

The results of the application of Equation 1 to the laboratory test data had an $\mathrm{R}^{2}$ of 0.70 (Wilkinson and Shikazono, 2012). Equation 1 was applied to the 609 selected wells, and the results are summarized in Table I. Since the results in Table I were somewhat inconsistent and generally too low, or too high, it was determined that Equation 1 would need to be revised. Therefore, the logarithmic version was discarded and research reverted back to the basic relationship that was used to establish the initial effective porosity (Wilkinson and Shikazono, 2012). The initial values of effective porosity were plotted against effective porosity calculated with Equation 1 and are shown in Figure 2. The fit generated for these data was in the form of a polynomial with an $\mathrm{R}^{2}$ of 0.998 :
Table I. Summary of the effective porosity from the application of Equation 1 for each hydrogeologic unit

\begin{tabular}{cc}
\hline Hydrogeologic Unit & Average Effecitive Porosity \\
\hline US & 1.38 \\
TG & 0.70 \\
C1 & 0.61 \\
TS & 0.60 \\
C2 & 0.64 \\
SG & 0.62 \\
UF & 0.68 \\
OR & 0.32 \\
\hline
\end{tabular}

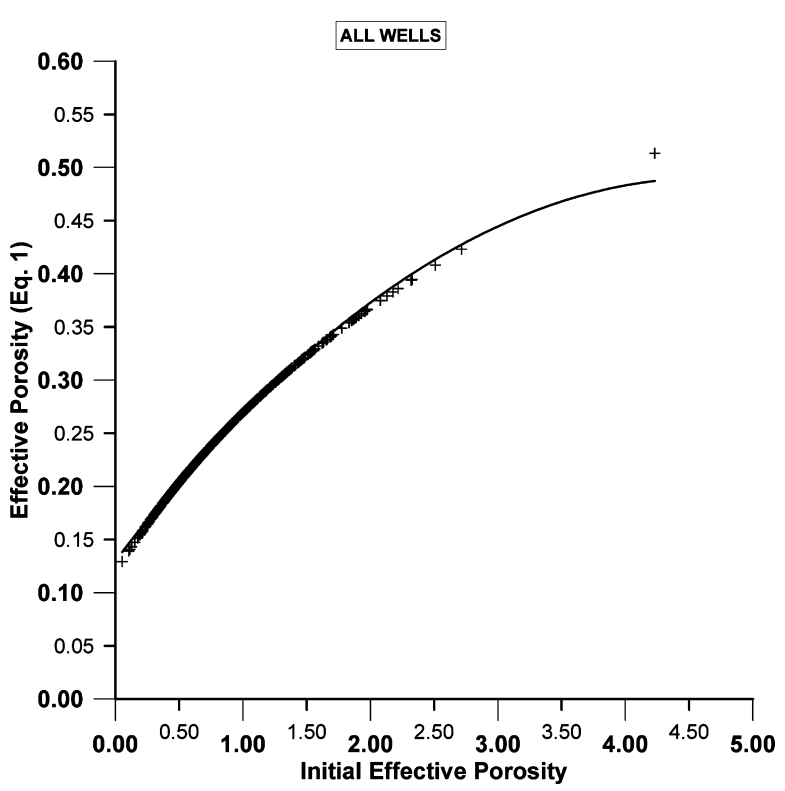

Figure 2. Plot of initial effective porosity versus the effective porosity calculated with Equation 1 for all wells

$$
\phi_{e}=0.1304+\left(0.1544 \phi_{i}\right)-\left(0.0165 \phi_{i}^{2}\right)
$$

where $\phi_{i}$ is the initial effective porosity. Expanding Equation 2 results in Equation 3,

$$
\begin{aligned}
\phi_{e}= & 0.1304+\left[1.1544 \times \sqrt[3.29]{\frac{\left(\frac{Q}{S}\right)^{0.67}}{11.992 b}}\right] \\
& -\left(0.0165 \times\left[\sqrt[3.29]{\frac{\left(\frac{Q}{S}\right)^{0.67}}{11.992 b}}\right]^{2}\right] .
\end{aligned}
$$

Equation 3 was applied to the initial effective porosity values and the results were plotted and are summarized in Table II. However, the equation that describes the fit has an $\mathrm{R}^{2}$ of 0.997 and is slightly different from Equation 3 . Therefore, through an iterative process of generating fit solutions and re-applying them to the initial effective porosity, Equation 4 was arrived at and used to calculate the effective porosity values: 
Table II. Summary of the effective porosity from the application of Equation 3 for each hydrogeologic unit

\begin{tabular}{cc}
\hline Hydrogeologic Unit & Average Effective Porosity \\
\hline US & 0.29 \\
TG & 0.22 \\
C1 & 0.20 \\
TS & 0.22 \\
C2 & 0.21 \\
UF & 0.21 \\
SG & 0.23 \\
OR & 0.19 \\
\hline
\end{tabular}

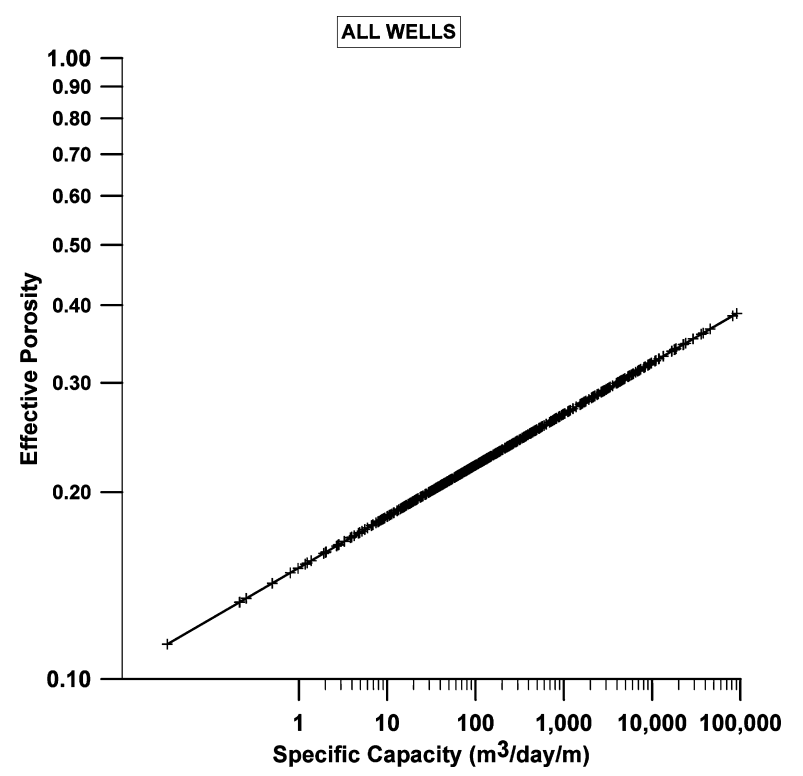

Figure 3. Plot of effective porosity versus specific capacity for all wells using Equation 6

$$
\phi_{e}=0.1301+\left(0.1544 \phi_{i}\right)-\left(0.0165 \phi_{i}{ }^{2}\right) .
$$

Expanding Equation 4 gives Equation 5:

$$
\begin{aligned}
\phi_{e}= & 0.1301+\left[1.154 \times \sqrt[3.29]{\frac{\left(\frac{Q}{S}\right)^{0.67}}{11.992 b}}\right] \\
& -\left(0.0165 \times\left[\sqrt[3.29]{\frac{\left(\frac{Q}{S}\right)^{0.67}}{11.992 b}}\right]^{2}\right] .
\end{aligned}
$$

The results of the application of Equation 5 were plotted against specific capacity calculated for the selected wells. The fit for this plot had an $\mathrm{R}^{2}$ of 0.71 and generated Equation 6:

$$
\phi_{e}=0.15108 \times\left(\frac{Q}{S}\right)^{0.0826} .
$$

Equation 6 was used to calculate effective porosity using

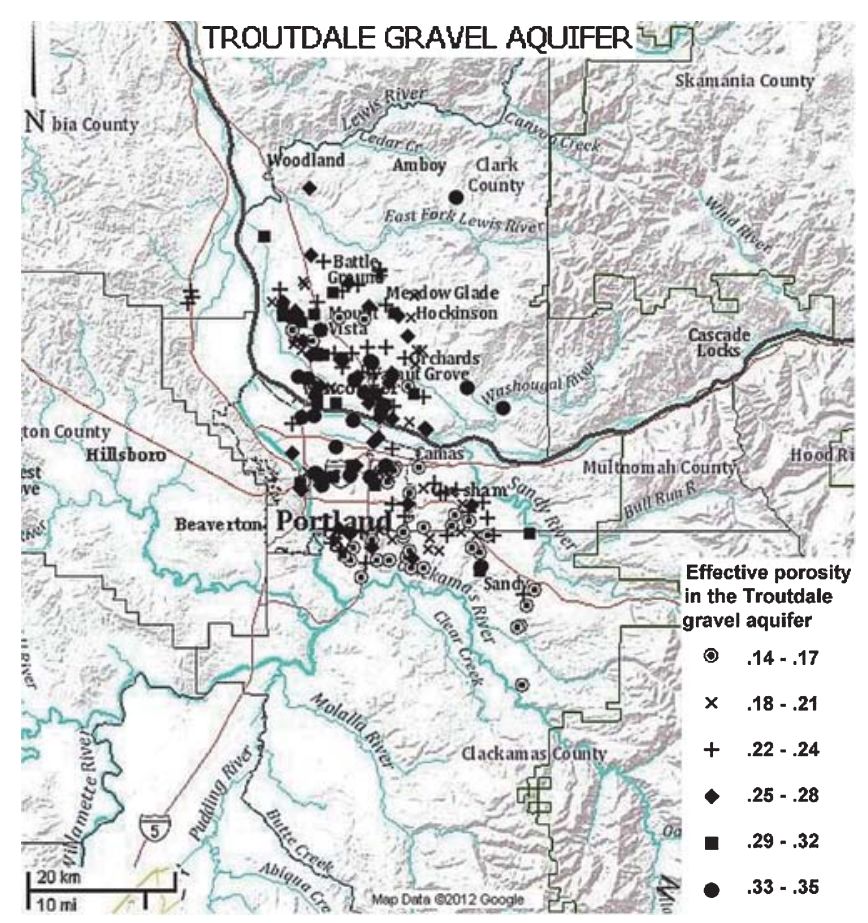

Figure 4. Distribution of effective porosity in wells in the Troutdale Gravel aquifer. Symbols denote specified ranges of calculated effective porosity values (Source: Google Maps)

only calculated specific capacity and is shown in Figure 3; the fit that was generated had an $\mathrm{R}^{2}$ of 1.0. Equation 6 was applied to the TG aquifer as shown in Figure 4.

\section{DISCUSSION}

The initial equation was based on a laboratory investigation that used 5 different sediment sizes. The initial equation satisfied the conditions of the sediments in the laboratory and established a basis for testing with a well database (Wilkinson and Shikazono, 2012). However, the hydrogeology in the study area is complex and does not reflect the very basic sediments and conditions used in the laboratory experiments. This was anticipated and the subsequent revisions were expected.

The application of the laboratory-generated initial equation was applied to the selected well data and produced values ranging from near $0 \%$ to over $400 \%$. Although a logarithm was used, the solution to the fit in Figure 2 turned out to be a polynomial; hence, the subsequent iterations were based on polynomial variations. Table II shows a very reasonable distribution and very little difference between Figures 2 and 3. However, there are differences in the full data sets calculated and used for Figures 2 and 3. Three iterations were needed to achieve an $\mathrm{R}^{2}$ of 1.0 .

The tables show clearly that there are substantial variations within each hydrogeologic unit and that the blanket value method used to cap effective porosity values at $31 \%$ in Hinkle and Snyder (1997) is not completely valid. The wells in the area yield from $27 \mathrm{~m}^{3}$ day $^{-1}$ up to 55,000 $\mathrm{m}^{3}$ day $^{-1}$ (Swanson et al., 1993), indicating very a large 
distribution of effective porosity values in the groundwater system and within each of the hydrogeologic units. To illustrate this point, the TG unit was isolated and the well locations plotted in Figure 4, based on effective porosity values. This unit was chosen because it is aerially extensive and has values of effective porosity ranging from 0.14 to 0.38 . These data are based on over 200 well records. Additionally, the effective porosity was calculated and plotted for each hydrogeologic unit. These were compared with the original maps of hydraulic conductivity published by Morgan and McFarland (1996) and used for calculating effective porosity. An analyses of these maps revealed that the hydraulic conductivity in $99 \%$ of the wells in the US unit, $41 \%$ of the wells in the TG unit, and $55 \%$ of the wells in the TS unit are above the cutoff level of $4.6 \mathrm{~m}^{3}$ day $^{-1}$, meaning that the effective porosity was assigned a value of $31 \%$ for those wells. It can be seen that effective porosity values vary considerably within the TG unit. The effective porosity varies spatially for each of the units in the basin and is not limited to $31 \%$. This type of analysis shows that there are variations in the composition of the TG aquifer, and possible stratification or facies changes.

\section{CONCLUSIONS}

Even though effective porosity is highly variable, Figure 3 shows that a relationship between effective porosity and specific capacity does exist, and in this study is represented in the metric system by Equation 6. However, it should be pointed out the main limitation is that this relationship is only as good as the data used for the calculations; if the pump test data is recent or if there is a time series record of water levels then the results will be more accurate. The well database contained wells completed in all 9 units, ranging from unconsolidated sediments to volcanic rocks. The relationship was used to calculate effective porosity values in each of these hydrogeologic units. This shows that the relationship is valid in all of these environments, and therefore valid for nearly any environment. Additionally, the equations in this paper are in SI units, but can be easily modified to use in other units of measure with information published by Razack and Huntley (1991).

The implications of the relationship are a major breakthrough in understanding the relationship between effective porosity and specific capacity. Since groundwater models, contaminant transport models, particle tracking models, and parameter estimation software are dependent on accurate values for effective porosity the relationship will contribute to the further refinement of such modeling programs. The relationship will also enable field personnel to readily calculate effective porosity at the drill site as drilling progresses. Additionally the relationship can be used to more accurately asses the volume of groundwater available in an aquifer.

\section{ACKNOWLEDGEMENTS}

Although the well data is in the public domain, the authors would like to acknowledge the US Geological Survey for the use and interpretation of their data.
Additionally numerous people helped with reviewing and providing helpful suggestions to improve this manuscript.

\section{REFERENCES}

Ahuja LR, Cassel DK, Bruce RR, Barnes BB. 1989. Evaluation of spatial distribution of hydraulic conductivity using effective porosity data. Soil Science 148: 404-411.

Barr DW. 2001. Coefficient of permeability determined by measurable parameters. Ground Water 39: 356-361. doi: 10.1111/j.1745-6584.2001.tb02318.x.

Bernabé Y, Mok U, Evans B, Herrmann F. 2004. Permeability and storativity of binary mixtures of high and low porosity materials. Journal of Geophysical Research 109: B12207. doi: 10.1029/2004JB003111.

Cunningham KJ. 2004. Application of ground-penetrating radar, digital optical borehole images, and cores for characterization of porosity hydraulic conductivity and paleokarst in the Biscayne aquifer, southeastern Florida, USA. Journal of Applied Geophysics 55: 61-76. doi: 10.1016/j.jappgeo.2003. 06.005 .

Dias RP, Teixeira JA, Mota MG, Yelshin AI. 2004. Particulate binary mixtures: Dependence of packing porosity on particle size ratio. Industrial \& Engineering Chemistry Research 43: 7912-7919. doi: 10.1021/ie040048b.

Domenico PA, Schwartz FW. 1991. Physical and Chemical Hydrogeology. John Wiley \& Sons Inc., $848 \mathrm{pp}$.

Driscoll FG. 1986. Groundwater and Wells (2nd ed.) Johnson Division, 1089 pp.

Dunning CP. 2005. Lithology, hydraulic properties, and water quality of the sandstone aquifer in the northwestern part of the Bad River Indian Reservation, Wisconsin, 1998-1999 (Open File Report No. 2004-1425). US Geological Survey, $47 \mathrm{pp}$.

Fetter CW. 2000. Applied Hydrogeology (4th ed.). Prentice Hall, $598 \mathrm{pp}$.

Gloaguen E, Chouteau M, Marcotte D, Chapuis R. 2001. Estimation of hydraulic conductivity of an unconfined aquifer using cokriging of GPR and hydrostratigraphic data. Journal of Applied Geophysics 47: 135-152. doi: 10.1016/S09269851(01)00057-X.

Haggerty R, Schroth M, Istok J. 1998. Simplified method of "pushpull" test data analysis for determining in situ reaction rate coefficients. Ground Water 36: 314-324. doi: 10.1111/j.17456584.1998.tb01097.x.

Hall SH, Luttrell SP, Cronin WE. 1991. A method for estimating effective porosity and ground-water velocity. Ground Water 29: 171-174. doi: 10.1111/j.1745-6584.1991.tb00506.x.

Hinkle S, Snyder DT. 1997. Comparison of chlorofluorocarbonage dating with particle-tracking results of a regional groundwater flow model of the Portland Basin, Oregon and Washington (Water Supply Paper No. 2483). US Geological Survey, $47 \mathrm{pp}$.

Jarvis N, Zavattaro L, Rajkai K, Reynolds W, Olsen PA, McGechan $\mathrm{M}$, Mecke M, et al. 2002. Indirect estimation of near-saturated hydraulic conductivity from readily available soil information. Geoderma 108: 1-17.

Javandel I. 1989. On the Field Determination of Effective Porosity. National Conference on New Field Techniques for Quantifying the Physical and Chemical Properties of Heterogeneous Aquifers, Dallas, TX, pp. 155-170.

Kamann PJ, Ritzi RW, Dominic DF, Conrad CM. 2007. Porosity and permeability in sediment mixtures. Ground Water 45: 429-438. doi: 10.1111/j.1745-6584.2007.00313.x.

McCarthy KA, Anderson DB. 1990. Ground-water data for the Portland basin, Oregon and Washington (Open File Report 
No. 90-126). US Geological Survey, $56 \mathrm{pp}$.

Morgan DS, McFarland WD. 1996. Simulation analysis of the ground-water flow system in the Portland basin (Water Supply Paper 2470-B). US Geological Survey, 83 pp.

Morin RH. 2006. Negative correlation between porosity and hydraulic conductivity in sand-and-gravel aquifers at Cape Cod, Massachusetts, USA. Journal of Hydrology, 316: 4352. doi: 10.1016/j.jhydrol.2005.04.013.

Morris DA, Johnson AI. 1967. Summary of hydrologic and physical properties of rock and soil materials, as analyzed by the hydrologic laboratory of the U.S. Geological Survey, 194860 (Water Supply Paper No. 1839-D). US Geological Survey, $42 \mathrm{pp}$.

Razack M, Huntley D. 1991. Assessing transmissivity from specific capacity in a large and heterogeneous alluvial aquifer. Ground Water 29: 856-861. doi: 10.1111/j.1745-6584.1991. tb00572.x.

Rojstaczer S, Agnew DC. 1989. The influence of formation material properties on the response of water levels in wells to Earth tides and atmospheric loading. Journal of Geophysical Research 94: 12403-12411. doi: 10.1029/JB094iB09p12403.

Snyder DT, Wilkinson JM, Orzol LL. 1998. Use of a ground-water flow model with particle tracking to evaluate ground-water vulnerability, Clark County, Washington (Water Supply Paper No. 2488). US Geological Survey, 72 pp.

Sperry JM, Peirce JJ. 1995. A model for estimating the hydraulic conductivity of granular material based on grain shape, grain size, and porosity. Ground Water 33: 892-898. doi: 10.1111/ j.1745-6584.1995.tb00033.x.

Stephens DB, Hsu KC, Prieksat MA, Ankeny MD, Blandford N,
Roth TL, Kelsey JA, Whitworth JR. 1998. A comparison of estimated and calculated effective porosity. Hydrogeology Journal 6: 156-165.

Swanson RD, McFarland WD, Gonthier JB, Wilkinson JM. 1993. A description of hydrogeologic units in the Portland basin, Oregon and Washington (Water Resources Investigation Report No. 90-4196). US Geological Survey, 56 pp.

Vandevivere P, Baveye P. 1992. Effect of bacterial extracellular polymers on the saturated hydraulic conductivity of sand columns. Applied and Environmental Microbiology 58: 1690.

Wang R, Mair RW, Rosen MS, Cory DG, Walsworth RL. 2003. Simultaneous measurement of rock permeability and effective porosity using laser-polarized noble gas NMR. Physical Review E 70: 026312. doi: 10.1103/PhysRevE.70.026312.

White PA. 1988. Measurement of ground-water parameters using salt-water injection and surface resistivity. Ground Water 26: 179-186. doi: 10.1111/j.1745-6584.1988.tb00381.x.

Wilkinson JM, Shikazono N. 2012. Experimental determination of effective porosity and specific capacity under controlled conditions in a laboratory. International Journal of Applied Environmental Sciences 7: 297-306.

Yeh Y, Lee C, Chen S. 2000. A tracer method to determine hydraulic conductivity and effective porosity of saturated clays under low gradients. Ground Water 38: 522-529. doi: 10.1111/ j.1745-6584.2000.tb00244.x.

Zhang ZF, Ward AL, Keller JM. 2011. Determining the porosity and saturated hydraulic conductivity of binary mixtures. Vadose Zone Journal 10: 313-321. doi: 10.2136/vzj2009. 0138. 